\title{
The Utilization of Historical Materials of The Dutch Age of Oil Exploration in Cepu in Historical Study at SMK Migas Cepu
}

\author{
Fitriah Hanim, Djono, Susanto \\ Universitas Sebelas Maret \\ fitriahhanim44@student.uns.ac.id
}

\author{
Article History \\ accepted 1/09/2020
}

approved 4/10/2020

published 1/12/2020

\begin{abstract}
History learning in Senior High Schools and Vocational High Schools is carried out almost the same, both obtaining mandatory history with the aim of studying the history of the nation. Meanwhile, studying history in Senior High Schools contains additional material for the history of specialization. The existence of differences in environment, meaning and purpose makes students less interested and meaningful in learning which results in history learning running less optimally. For this reason, this paper aims to make historical learning relevant to the learning field of Vocational Middle School students, one of which is by utilizing local material in areas close to the environment and even the vocational school. One of them is the use of local materials for the Cepu Oil and Gas Vocational Middle School students, namely the history of Dutch oil exploration in Cepu. This study uses a literature study research method, the authors use a humanistic approach to analyze the relevance of learning materials to the learning environment and the interests or vocational of students. The focus of this research is on discussing history learning in Vocational High Schools and the use of historical material on Dutch oil exploration in Cepu as a learning resource. So that studying history will be relevant and meaningful in accordance with the vocational.
\end{abstract}

Keywords: History learning in vocational high schools, utilization of local materials, humanistic approach

\begin{abstract}
Abstrak
Pembelajaran sejarah di Sekolah Menengah Atas dan Sekolah Menengah Kejuruan terlaksana hampir sama, sama-sama mendapatkan sejarah wajib dengan tujuan untuk mempelajari sejarah bangsa. Sementara pembelajaran sejarah di Sekolah Menengah Atas terdapat tambahan materi sejarah peminatan. Adanya perbedaan lingkungan, kebermaknaan dan tujuan membuat peserta didik kurang tertarik dan bermakna dalam mempelajarinya yang mengakibatkan pembelajaran sejarah berjalan kurang maksimal. Untuk itu, makalah ini bertujuan membuat pembelajaran sejarah yang relevan dengan bidang pembelajaran peserta didik Sekolah Menengah Kejuruan salah satunya dengan memanfaatkan materi lokal di daerah yang dekat dengan lingkungan bahkan kejuruannya. Salah satunya pemanfaatan materi lokal pada peserta didik Sekolah Menengah Kejuruan Migas Cepu yaitu sejarah eksplorasi minyak zaman Belanda di Cepu. Penelitian ini menggunakan metode penelitian studi pustaka, penulis menggunakan pendekatan humanistik untuk menganalisis relevansi materi pembelajaran dengan lingkungan belajar dan minat atau kejuruan peserta didik. Fokus penelitian ini pada pembahasan pembelajaran sejarah di Sekolah Menengah Kejuruan dan pemanfaatan materi sejarah eksplorasi minyak Belanda di Cepu sebagai sumber belajar. Sehingga mempelajari sejarah itu akan relevan dan bermakna sesuai dengan kejuruannya.
\end{abstract}

Kata kunci : Pembelajaran sejarah di sekolah menengah kejuruan, pemanfaatan materi lokal, pendekatan humanistic

Social, Humanities, and Education Studies (SHEs): Conference Series https://jurnal.uns.ac.id/shes

p-ISSN 2620-9284

e-ISSN 2620-9292 


\section{PENDAHULUAN}

Perbedaan pembelajaran di semua jenjang tergantung pada tujuan akhir dari pembelajaran tersebut. Tujuan akhir inilah yang kemudian menjadi permasalahan dalam proses pencapaiannya. Realita di lapangan, pembelajaran sejarah di SMA dan SMK berbeda karena memang akhir dari tujuan pembelajaran sejarah tersebut berbeda. di SMK tujuan akhir dalam pembelajaran menurut (Fachrurozi 2016) adalah mempersiapkan peserta didik untuk memasuki dunia kerja baik berupa hardskill maupun softskill. Ketika ditarik dalam pembelajaran sejarah apakah pembelajaran sejarah sudah sesuai dengan hal tersebut, apakah sudah menyesuaikan dengan lingkungan dan minat kejuruanya. Inilah yang kemudian membuat matapelajaran sejarah yang diajarkan di SMK selain karena permasalahan metode mengajar, sumber belajar, media belajar adalah terletak pada belum terkaitnya materi mata pelajaran pada visi misi di SMK sendiri yaitu link and match. Selain tantangan itu, pelajaran sejarah juga dituntut untuk mengenalkan karakteristik, membentuk identitas bangsa dan dan mewujudkan integrasi nasional agar tidak kehilangan jati dirinya (Nur Fajar, Umasih, and Kurniawati 2019)

Tujuan pembelajaran sejarah yang belum tercapai tersebut, menurut (Alfian 2011) pembelajaran sejarah selama ini hanya mengedepankan urutan fakta sejarah sebagai materi utama sehingga tidak mengherankan jika peserta didik kurang tertarik. Begitupun dengan banyaknya mata pelajaran ilmu sosial membuat peserta didik merasa bosan, apalagi dengan mempelajari pendekatan yang cenderung teoritis dan kurang relevan dengan pasar tenaga kerja. (Suharno, Pambudi, and Harjanto 2020)

Menjembatani kesenjangan dan tetap melaksanakan tujuan dari pelajaran sejarah serta visi misi SMK tersebut, maka dibuatlah materi yang tetap sesuai Kompetensi Dasar mata pelajaran sejarah yang kemudian dikaitkan dengan lokalitas dan kejuruan peserta didik. menurut (Sartono 1992) pembelajaran harus menggunakan pendekatan lokosentris yaitu mengaitkan pada sejarah lokal. Pendapat tersebut juga diperkuat oleh (Wijayanti 2017) lokalitas itu sangat penting karena terkait dengan lingkungan hidup, kehidupan sehari-hari (budaya, sosial, ekonomi), pemahaman keyakinan peserta didik. Begitupun dengan konten kurikulum sejarah yang tidak hanya bersifat profresif, melainkan menggunakan pendekatan yang dekat dengan lingkungan peserta didik, dimana peserta didik belajar dari lingkungan yang dekat kemudian baru ke lingkungan yang paling jauh. (Hasan 2006)

Terlebih lagi lokalitas tersebut ada kaitannya juga dengan kejuruan peserta didik yang dalam hal ini adalah pada Sekolah Menengah Kejuruan (SMK) Migas Cepu. Lokalitas yang penting untuk dikaji dalam hal ini adalah tentang sejarah eksplorasi minyak zaman Belanda di Cepu. Hal ini menjadi penting karena lingkungan sekolah yang berada pada area pertambangan minyak yang sejarahnya belum pernah disampaikan pada saat pembelajaran sejarah dan baground sekolah yang memiliki jurusan perminyakan. Dengan menyampaikan pentingnya mempelajari sejarah perminyakan ini akan menjadikan bekal siswa dikemudian hari jika bekerja dalam dunia perminyakan.

Sehingga tujuan penelitian ini adalah membuat pembelajaran sejarah yang relevan dengan bidang pembelajaran siswa SMK salah satunya dengan memanfaatkan materi lokal di daerah yang dekat dengan lingkungan bahkan kejuruannya.

\section{METODOLOGI}

Penelitian ini menggunakan teori humanistik, dimana teori humanitsik menganggap bahwa belajar dianggap berhasil apabila pelajar memahami lingkungan dan dirinya. Teori belajar yang memahami perilaku belajar dari sudut pandang yang belajar (peserta didik) bukan dari sudut pandang pengamatnya (pendidik). Teori Humanistik yang dipakai dalam hal ini adalah teori humanistik dari Arthur Combs (19221999) bahwa pendidik tidak bisa memaksakan materi yang tidak disukai atau tidak relevan dengan kehidupan peserta didik. Combs sendiri berpendapat bahwa banyak 
pendidik yang melakukan kesalahan dengan asumsi bahwa peserta didik mau belajar jika pelajarannya disusun atau disajikan sebagaimana mestinya. Padahal yang terpenting bukanlah hal itu, melainkan pendidik mampu membawa peserta didik untuk memperoleh arti pribadinya dari materi pelajaran dan menghubungkan dengan kehidupannya. (Novina Suprobo 2018)

Teori Humanistik dirasa sesuai dengan penelitian ini karena penelitian ini ingin melihat pembelajaran dari segi peserta didik, materi yang sesuai dengan lingkungan dan kebutuhan peserta didik, yaitu tentang ekplorasi minyak Zaman Belanda di Cepu, sehingga peserta didik akan memahami pentingnya belajar sejarah dari lingkungan terdekatnya.

Berdasarkan pemaparan tersebut, penulis bermaksud mengkaji secara empiris tentang pemanfaatan materi sejarah eksplorasi minyak zaman belanda di cepu pada mata pelajaran sejarah di SMK Migas Cepu. Tulisan ini mengunakan metodelogi penelitian kualitatif deskriptif dengan pendekatan studi kasus. Studi kasus merupakan salah satu jenis penelitian kualitatif yang mengkaji tentang suatu kasus dalam relitas kehidupan dalam konteks kontemporer (Creswell 2015). Teknik pengumpulan data yang digunakan dalam penelitian ini yaitu observasi-partisipasi, kajian pustaka, wawancara, dan dokumentasi.

Proses pengumpulan data penelitian ini disesuaikan dengan jenis penelitian. Data yang dihimpun dalam penelitian ini berupa kata-kata, tindakan dan dokumen, situasi dan peristiwa yang dapat diobservasi (Moleong 2007). Sumber data tersebut adalah:

1. Kata-kata yang didapat baik secara langsung maupun tidak langsung melalui wawancara dan observasi.

2. Dokumen dalam penelitian ini berupa kurikulum Satuan Pembelajaran, Rencana Pelaksanaan Pembelajaran.

3. Situasi yang dimaksud dalam penelitian ini berkaitan dengan kegiatan subjek penelitian dan masalah penelitian seperti dalam proses belajar mengajar dan situasi di lingkungan sekolah.

\section{HASIL DAN PEMBAHASAN}

\section{Pelajaran Sejarah di SMK dalam Kurikulum 2013 Revisi 2017}

Berdasarkan Surat Keputusan Direktur Jendral Pendidikan Dasar dan Menengah Kementrian Pendidikan Dan Kebudayaan Nomor: 07/D.D5/KK/2018 (Minister of Education and Culture 2018) Tentang Struktur Kurikulum Sekolah Menengah Kejuruan (SMK) pada mata pelajaran sejarah dari 144 jam pada revisi 2016 yang diberikan di kelas X dan XI menjadi 108 jam pelajaran di kelas X.

Alasan mendasar adanya perubahan struktur kurikulum dengan materi yang biasanya diajarkan di kelas X-XII, berdasarkan SK Dirjen Disdasmen No 180/D/KEP/KR/2017 yang diajarkan pada matapelajaran sejarah bukan pengetahuan fakta atau periodisasi melainkan nilai yang terkandung di dalam setiap peristiwa. Alasan yang lain, di tingkat SMK untuk kelas XI dan XII difokuskan pada materi kejuruannya. Perbandingan tersebut dapat dilihat pada stuktur kurikulum di SMK. Berdasarkan struktur kurikulum SMK, pada sekolah SMK Migas Cepu bidang keahlian Perminyakan terdapat tiga kompetensi keahlian yaitu PRD, BOR dan PMP yaitu sebagai berikut:

Tabel1. Struktur Kurikulum SMK

\begin{tabular}{ll}
\hline MATA PELAJARAN & ALOKASI \\
WAKTU
\end{tabular}

A. MUATAN NASIONAL

1. Pendidikan Agama dan Budi Pekerti 318

2. Pendidikan Pancasila dan Kewarganegaraan 212 


\begin{tabular}{|c|c|}
\hline Bahasa Indonesia & 320 \\
\hline Matematika & 424 \\
\hline Sejarah Indonesia & 108 \\
\hline Bahasa Inggris dan Bahasa Asing Lainnya*) & 352 \\
\hline Jumlah A & 1.734 \\
\hline \multicolumn{2}{|l|}{ B. Muatan Kewilayahan } \\
\hline Seni Budaya & 108 \\
\hline Pendidikan Jasmani, Olahraga dan Kesehatan & 144 \\
\hline Jumlah B & 252 \\
\hline \multicolumn{2}{|l|}{ C. Muatan Peminatan Kejuruan } \\
\hline \multicolumn{2}{|l|}{ C1. Dasar Bidang Keahlian } \\
\hline Simulasi dan Komunikasi Digital & 108 \\
\hline Fisika & 144 \\
\hline 3. Kimia & 108 \\
\hline \multicolumn{2}{|l|}{ C2. Dasar Program Keahlian } \\
\hline 1. Gambar Teknik & 108 \\
\hline Geologi Dasar & 108 \\
\hline Pengetahuan Industri Migas & 216 \\
\hline \multicolumn{2}{|l|}{ C3. Kompetensi Keahlian } \\
\hline Teknik Reservoir & 144 \\
\hline Proses Produksi Migas & 420 \\
\hline Teknik Produksi Migas & 496 \\
\hline Peralatan Produksi Atas dan Bawah Permukaan & 454 \\
\hline Produk Kreatif dan Kewirausahaan & 524 \\
\hline Jumlah C & 3.030 \\
\hline Total & 5.016 \\
\hline
\end{tabular}

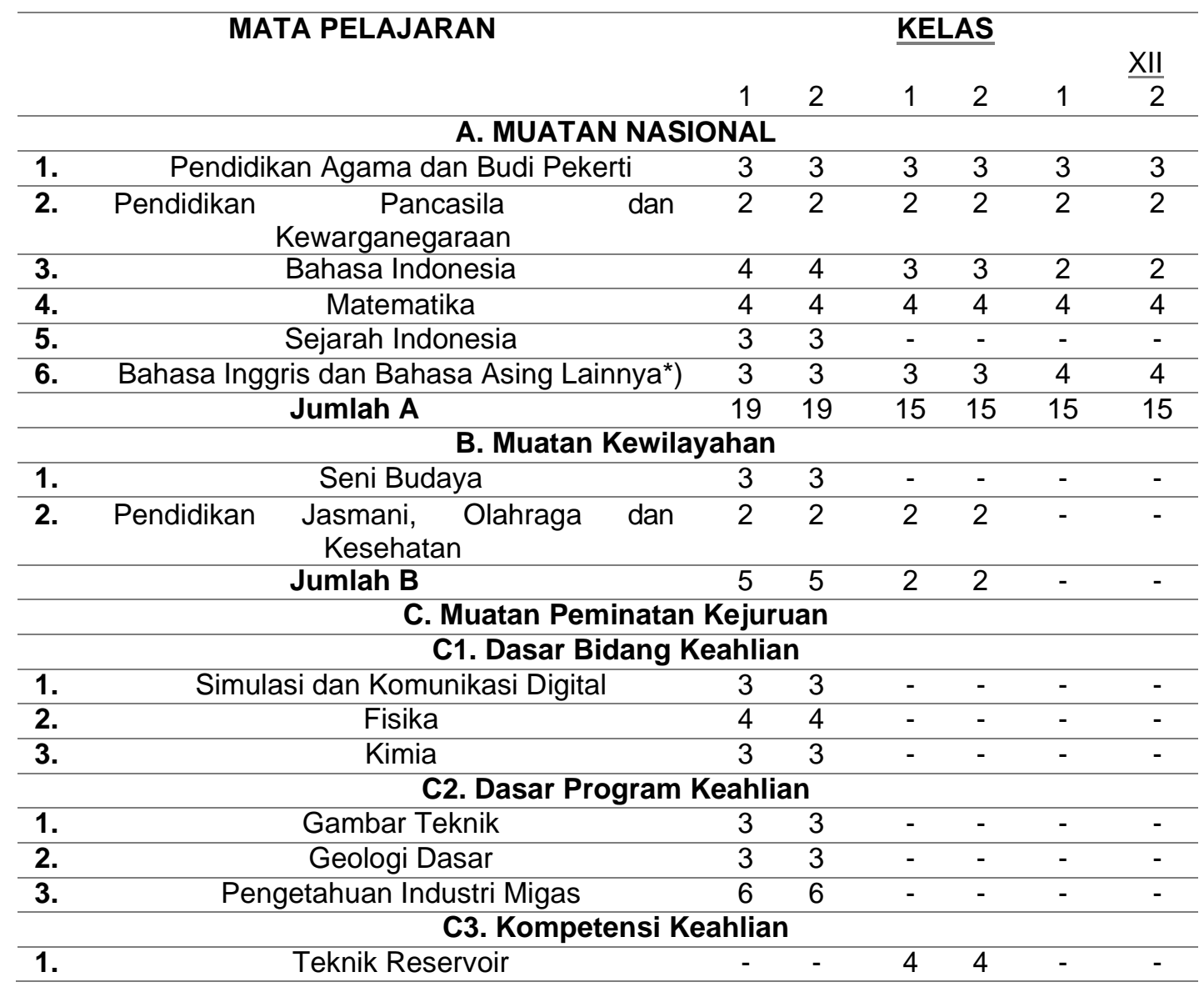




\begin{tabular}{|c|c|c|c|c|c|c|c|}
\hline 2. & Proses Produksi Migas & - & - & 6 & 6 & 6 & 6 \\
\hline 3. & Teknik Produksi Migas & - & - & 8 & 8 & 12 & 12 \\
\hline 4. & $\begin{array}{cc}\text { Peralatan } & \begin{array}{c}\text { Produksi Atas dan } \\
\text { Permukaan }\end{array}\end{array}$ & - & - & 6 & 6 & 7 & 7 \\
\hline 5. & Produk Kreatif dan Kewirausahaan & - & - & 7 & 7 & 8 & 8 \\
\hline & Jumlah C & 22 & 22 & 31 & 31 & 33 & 33 \\
\hline & Total & 46 & 46 & 48 & 48 & 48 & 48 \\
\hline
\end{tabular}

Kompetensi Keahlian : Teknik Pemboran Minyak dan Gas (BOR)

\begin{tabular}{|c|c|c|}
\hline & MATA PELAJARAN & $\begin{array}{l}\text { ALOKASI } \\
\text { WAKTU }\end{array}$ \\
\hline \multicolumn{3}{|c|}{ A. MUATAN NASIONAL } \\
\hline 1. & Pendidikan Agama dan Budi Pekerti & 318 \\
\hline 2. & Pendidikan Pancasila dan Kewarganegaraan & 212 \\
\hline 3. & Bahasa Indonesia & 320 \\
\hline 4. & Matematika & 424 \\
\hline 5. & Sejarah Indonesia & 108 \\
\hline 6. & Bahasa Inggris dan Bahasa Asing Lainnya*) & 352 \\
\hline & Jumlah A & 1.734 \\
\hline \multicolumn{3}{|c|}{ B. Muatan Kewilayahan } \\
\hline 1. & Seni Budaya & 108 \\
\hline 2. & Pendidikan Jasmani, Olahraga dan Kesehatan & 144 \\
\hline & Jumlah B & 252 \\
\hline \multicolumn{3}{|c|}{ C. Muatan Peminatan Kejuruan } \\
\hline \multicolumn{3}{|c|}{ C1. Dasar Bidang Keahlian } \\
\hline 1. & Simulasi dan Komunikasi Digital & 108 \\
\hline 2. & Fisika & 144 \\
\hline 3. & Kimia & 108 \\
\hline \multicolumn{3}{|c|}{ C2. Dasar Program Keahlian } \\
\hline 1. & Gambar Teknik & 108 \\
\hline 2. & Geologi Dasar & 108 \\
\hline 3. & Pengetahuan Industri Migas & 216 \\
\hline \multicolumn{3}{|c|}{ C3. Kompetensi Keahlian } \\
\hline 1. & Teknik Pemboran & 524 \\
\hline 2. & Peralatan Pemboran & 490 \\
\hline 3. & Lumpur dan Hidrolika Lumpur Pemboran & 316 \\
\hline 4. & Hambatan Pemboran & 384 \\
\hline \multirow[t]{3}{*}{5.} & Produk Kreatif dan Kewirausahaan & 524 \\
\hline & Jumlah C & 3.030 \\
\hline & Total & 5.016 \\
\hline
\end{tabular}

MATA PELAJARAN

$\underline{\text { KELAS }}$

\section{A. MUATAN NASIONAL}

\begin{tabular}{|c|c|c|c|c|c|c|c|c|c|}
\hline 1. & \multicolumn{3}{|c|}{ Pendidikan Agama dan Budi Pekerti } & 3 & 3 & 3 & 3 & 3 & 3 \\
\hline 2. & \multirow{2}{*}{\multicolumn{3}{|c|}{$\begin{array}{c}\text { Kewarganegaraan } \\
\text { Bahasa Indonesia }\end{array}$}} & 2 & 2 & 2 & 2 & 2 & 2 \\
\hline 3. & & & & 4 & 4 & 3 & 3 & 2 & 2 \\
\hline 4. & \multicolumn{3}{|c|}{ Matematika } & 4 & 4 & 4 & 4 & 4 & 4 \\
\hline 5. & \multicolumn{3}{|c|}{ Sejarah Indonesia } & 3 & 3 & - & - & - & - \\
\hline 6. & \multirow{2}{*}{\multicolumn{3}{|c|}{$\begin{array}{c}\text { Bahasa Inggris dan Bahasa Asing Lainnya*) } \\
\text { Jumlah A }\end{array}$}} & 3 & 3 & 3 & 3 & 4 & 4 \\
\hline & & & & 19 & 19 & 15 & 15 & 15 & 15 \\
\hline
\end{tabular}




\section{B. Muatan Kewilayahan}

\begin{tabular}{|c|c|c|c|c|c|c|c|}
\hline 1. & Seni Budaya & 3 & 3 & - & - & - & - \\
\hline 2. & $\begin{array}{l}\text { Jasmani, Olahraga dan } \\
\text { Kesehatan }\end{array}$ & 2 & 2 & 2 & 2 & - & - \\
\hline & Jumlah B & 5 & 5 & 2 & 2 & - & - \\
\hline \multicolumn{8}{|c|}{ C. Muatan Peminatan Kejuruan } \\
\hline \multicolumn{8}{|c|}{ C1. Dasar Bidang Keahlian } \\
\hline 1. & Simulasi dan Komunikasi Digital & 3 & 3 & - & - & - & - \\
\hline 2. & Fisika & 4 & 4 & - & - & - & - \\
\hline 3. & Kimia & 3 & 3 & - & - & - & - \\
\hline \multicolumn{8}{|c|}{ C2. Dasar Program Keahlian } \\
\hline 1. & Gambar Teknik & 3 & 3 & - & - & - & - \\
\hline 2. & Geologi Dasar & 3 & 3 & - & - & - & - \\
\hline 3. & Pengetahuan Industri Migas & 6 & 6 & - & - & - & - \\
\hline \multicolumn{8}{|c|}{ C3. Kompetensi Keahlian } \\
\hline 1. & Teknik Pemboran & - & - & 7 & 7 & 8 & 8 \\
\hline 2. & Peralatan Pemboran & - & - & 7 & 7 & 7 & 7 \\
\hline 3. & Lumpur dan Hidrolika Lumpur Pemboran & - & - & 5 & 5 & 4 & 4 \\
\hline 4. & Hambatan Pemboran & - & - & 5 & 5 & 6 & 6 \\
\hline 5. & Produk Kreatif dan Kewirausahaan & - & - & 7 & 7 & 8 & 8 \\
\hline & Jumlah C & 22 & 22 & 31 & 31 & 33 & 33 \\
\hline & Total & 46 & 46 & 48 & 48 & 48 & 48 \\
\hline
\end{tabular}

Kompetensi Keahlian : Teknik Pengolahan Minyak, Gas dan Petrokimia

MATA PELAJARAN

ALOKASI

A. MUATAN NASIONAL

WAKTU

1.

Pendidikan Agama dan Budi Pekerti

318

2.

3.

4.

ancasila dan Kewarganegaraan

320

Bahasa Indonesia 424

5. Matematika 108

6. Sejarah Indonesia

352

\section{Jumlah A}

1.734

\section{B. Muatan Kewilayahan}

1. Seni Budaya

2. Pendidikan Jasmani, Olahraga dan Kesehatan

\section{Muatan Peminatan Kejuruan}

C1. Dasar Bidang Keahlian

1.

2.

3.

Simulasi dan Komunikasi Digital

Fisika

1.

C2. Dasar Program Keahlian Gambar Teknik

108

Geologi Dasar

108

3.

Pengetahuan Industri Migas

216

\section{C3. Kompetensi Keahlian}

1.

Teknik Instrumentasi Kilang

2.

engolahan Minyak, Gas dan Petrokimia

3.

Peralatan Proses dan Utilitas

350

4.

Produk Migas dan Storage Handling

420

5.

6.

Produk Kreatif dan Kewirausahaan 524 


\begin{tabular}{cc}
\hline Jumlah C & 3.030 \\
\hline Total & 5.016 \\
\hline
\end{tabular}

\begin{tabular}{|c|c|c|c|c|c|c|c|}
\hline \multicolumn{2}{|r|}{ MATA PELAJARAN } & \multicolumn{6}{|c|}{ KELAS } \\
\hline & & & & & & & XII \\
\hline & & 1 & 2 & 1 & 2 & 1 & 2 \\
\hline \multicolumn{8}{|c|}{ A. MUATAN NASIONAL } \\
\hline 1. & Pendidikan Agama dan Budi Pekerti & 3 & 3 & 3 & 3 & 3 & 3 \\
\hline 2. & Pendidikan Pancasila dan Kewarganegaraan & 2 & 2 & 2 & 2 & 2 & 2 \\
\hline 3. & Bahasa Indonesia & 4 & 4 & 3 & 3 & 2 & 2 \\
\hline 4. & Matematika & 4 & 4 & 4 & 4 & 4 & 4 \\
\hline 5. & Sejarah Indonesia & 3 & 3 & - & - & - & - \\
\hline 6. & Bahasa Inggris dan Bahasa Asing Lainnya*) & 3 & 3 & 3 & 3 & 4 & 4 \\
\hline & Jumlah A & 19 & 19 & 15 & 15 & 15 & 15 \\
\hline \multicolumn{8}{|c|}{ B. Muatan Kewilayahan } \\
\hline 1. & Seni Budaya & 3 & 3 & - & - & - & - \\
\hline 2. & Pendidikan Jasmani, Olahraga dan Kesehatan & 2 & 2 & 2 & 2 & - & - \\
\hline & Jumlah B & 5 & 5 & 2 & 2 & - & - \\
\hline \multicolumn{8}{|c|}{ C. Muatan Peminatan Kejuruan } \\
\hline \multicolumn{8}{|c|}{ C1. Dasar Bidang Keahlian } \\
\hline 1. & Simulasi dan Komunikasi Digital & 3 & 3 & - & - & - & - \\
\hline 2. & Fisika & 4 & 4 & - & - & - & - \\
\hline 3. & Kimia & 3 & 3 & - & - & - & - \\
\hline \multicolumn{8}{|c|}{ C2. Dasar Program Keahlian } \\
\hline 1. & Gambar Teknik & 3 & 3 & - & - & - & - \\
\hline 2. & Geologi Dasar & 3 & 3 & - & - & - & - \\
\hline 3. & Pengetahuan Industri Migas & 6 & 6 & - & - & - & - \\
\hline \multicolumn{8}{|c|}{ C3. Kompetensi Keahlian } \\
\hline 1. & Teknik Instrumentasi Kilang & - & - & 4 & 4 & 6 & 6 \\
\hline 2. & Proses Pengolahan Minyak, Gas dan Petrokimia & - & - & 5 & 5 & 6 & 6 \\
\hline 3. & Peralatan Proses dan Utilitas & - & - & 5 & 5 & 5 & 5 \\
\hline 4. & Produk Migas dan Storage Handling & - & - & 6 & 6 & 6 & 6 \\
\hline 5. & Gas Processing & - & - & 4 & 4 & 4 & 4 \\
\hline \multirow[t]{3}{*}{6.} & Produk Kreatif dan Kewirausahaan & - & - & 7 & 7 & 8 & 8 \\
\hline & Jumlah C & 22 & 22 & 31 & 31 & 33 & 33 \\
\hline & Total & 46 & 46 & 48 & 48 & 48 & 48 \\
\hline
\end{tabular}

Dilihat dari Struktur kurikulum progam keahlian perminyakan, alokasi waktu pada mata pelajaran kejuruan lebih banyak dibandingkan dengan pelajaran sejarah. Dapat diambil satu contoh dari kompetensi keahlian Teknik Pengolahan Minyak, Gas dan Petrokimia (PMP) yang alokasinya paling sedikit yaitu mapelteknik instrumentasi kilang dan Gas Processing berjumlah $280 \mathrm{JP}$ sedangkan jam mata pelajaran sejarah hanya 180 JP. Terdapat ketimpangan yang jauh antara ke dua mapel tersebut, yang memang berdasarkan tujuannya di SMK difokuskan pada mata pelajaran kejuruannya. Sedangkan materi-materi yang diajarkan pada mata pelajaran sejarah berdasarkan KI dan KD Kurikulum 2013 Revisi 2017 masih sama dengan kurikulum 2013 awal yaitu sebagai berikut:

Tabe 2. Sebaran Materi

\begin{tabular}{cl}
\hline No & \multicolumn{1}{c}{ Materi } \\
\hline 1. & Konsep berpikir diakronik, sinkronik, ruang, waktu dalam sejarah \\
\hline 2. & Masa praaksara \\
\hline
\end{tabular}




\begin{tabular}{cl}
\hline 3. & Masa Kerajaan Hindu-Buddha \\
\hline $\mathbf{4 .}$ & Masa Kerajaan-kerajaan Islam \\
\hline $\mathbf{5 .}$ & Kolonialisme Barat di Indonesia \\
\hline $\mathbf{6 .}$ & Pergerakan Nasional \\
\hline $\mathbf{8 .}$ & Proklamasi \\
\hline $\mathbf{9 .}$ & Revolusi Kemerdekaan \\
\hline $\mathbf{1 0}$ & Disintegrasi Bangsa \\
\hline $\mathbf{1 1 .}$ & Demokrasi Liberal \& Demokrasi Terpimpin \\
\hline $\mathbf{1 2}$. & Peran Indonesia dalam perdamaian dunia Pengembangan IPTEK dari \\
& Kemerdekaan-Reformasi \\
\hline
\end{tabular}

Berdasarkan struktur kurikulum dan organisasi materi, mata pelajaran sejarah kurikulum 2013 revisi 2017 terdapat 3 jam pelajaran, hanya diajarkan di kelas X dan materinya adalah materi sejarah yang pada kurikulum 2013 sebelumnya diajarkan di kelas X sampai kelas XII. Efektifitas dari penyampaian materi tersebut sangat diragukan karena dengan materi yang padat dan waktu yang terbatas. Fakta dilapangan banyak guru yang mengeluh karena materi yang padat dan hanya diberikan dalam jangka satu tahun.(Pratama and Lestari 2019)

\section{Pemanfaatan Materi Sejarah Eksplorasi Minyak Belanda di Cepu sebagai Sumber Belajar}

Padatnya materi yang tidak efektif dan tidak relevan dengan kondisi serta kebermanfaatan peserta didik, tentunya tanpa mengurangi tujuan kurikulum, memanfaatkan materi sejarah lokal sebagai sumber belajar sangatlah tepat. Pengajaran sejarah lokal membawa murid memahami dan mengenal lingkungan yang merupakan bagian dari dirinya dan memudahkan seorang guru untuk membawa siswanya menempatkan pengalaman masa lampau masyarakat dengan keadaan massa kini sebagai arahan untuk masa depannya, terlebih lagi akan dapat meningkatkan pengetahuan daerahnya yang akan meimbulkan rasa bangga dan meningkatkan rasa cinta tanah air pada budaya dan sejarahnya (Yuliana, n.d.). Sejarah lokal tidak hanya sebatas mengembangkan jati diri, budaya dan sosial peserta didik tapi, tetapi mempunyai peranan yang cukup penting untuk menumbuhkan kesadaran nasional (Fachrurozi 2016). Pentingnya sejarah lokal yang membawa kebermaknaan belajar bagi peserta didik sangat tepat sekali untuk dieksplor dan diajarkan ke peserta didik, lebih lagi pada peserta didik SMK yang matapelajaran sejarahnya dipadatkan dan peserta didik merasa apa yang dipelajari kurang relevan dengan dunia kerja. Untuk itu memanfaatkan materi lokal sangatlah tepat, yaitu dengan mengajarkan sejarah eksplorasi minyak zaman Belanda di Cepu.

Beberapa penlitian tentang sumber minyak di Cepu sudah lumayan banyak, seperti penelitian yang dilakukan : Siti Nur Fatimah, Wasino, B dengan judul "Nasionalisasi Tambang Minyak di Cepu dan Pengelolaannya Tahun 1950-1966", Sulistyono, S., Suntoro, S., \& Masykuri, M, dengan judul "Kajian dampak tumpahan minyak dari kegiatan operasi kilang minyak terhadap kualitas air dan tanah (Studi Kasus Kilang Minyak Pusdiklat Migas Cepu)", dan Rochmaningrum, Fahmi dengan judul 'Perkembangan Tambang Minyak Blok Cepu dan Pengaruhnya Terhadap Sosial Ekonomi Masyarakat Desa Ledok Tahun 1960-2004". Tetapi, dari penelitian tersebut belum pernah disampaikan atau dipraktikan di kelas. Terlebih lagi materi ini sangat bermanfaat untuk disampaikan pada peserta didik SMK Migas Cepu sebagai bekal pengetahuan ketika nanti bekerja di dunia perminyakan.

Menyesuaikan dengan perkembangan teknologi 4.0 dan perkembangan peserta didik, materi sejarah eksplorasi minyak zaman Belanda di Cepu dapat dikemas melalui 
bahan ajar digital dan dengan menggunakan model guded inquiry. Materi sejarah lokal tersebut dapat dimasukkan pada KD 3.5 yaitu tentang Menganalisis proses masuk dan perkembangan penjajahan Bangsa Eropa (Portugis, Spanyol, Belanda dan Inggris) ke Indonesia.

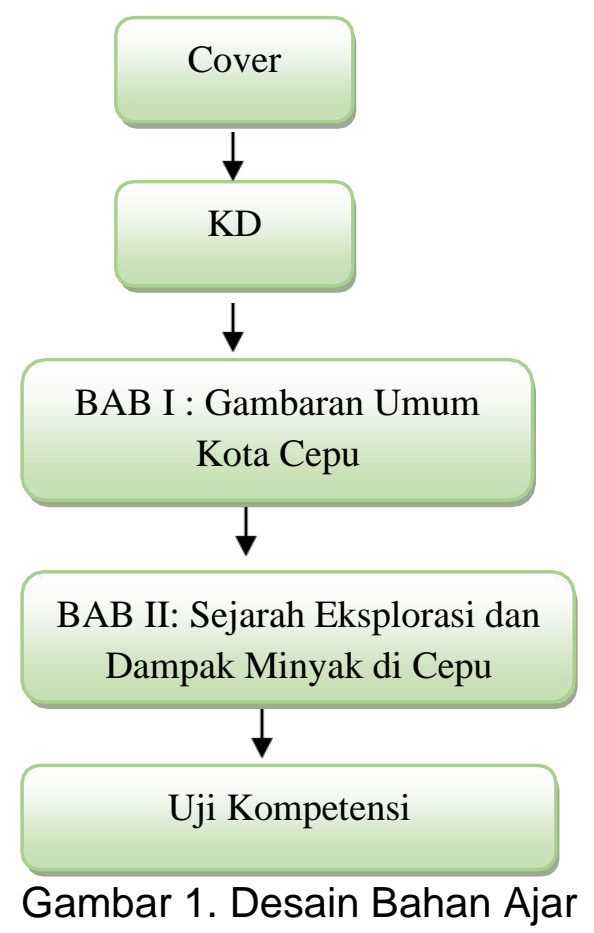

RENCANA PELAKSANAAN PEMBELAJARAN (RPP)

Nama Satuan Pendidikan : SMK Migas Cepu

Mata Pelajaran : Sejarah Indonesia

Kelas/Semester : : X/ Ganjil

Materi Pokok : Kedatangan Belanda di Indonesia

Sub Materi : : Sejarah Ekplorasi Minyak Belanda di Cepu

Alokasi Waktu : 3x 45 Menit

\section{Tujuan Pembelajaran}

Melalui diskusi di kelas tentang sejarah eksplorasi minyak zaman Belanda di Cepu, dengan model pembelajaran guided inquiry dan bahan ajar digital, peserta didik mampu menganalisis sejarah eksplorasi minyak zaman Belanda di Cepu dengan tepat.

2 Langkah-langkah Pembelajaran

\begin{tabular}{|l|l|}
\hline RINCIAN KEGIATAN & WAKTU \\
\hline Kegiatan Pendahuluan & 10 Menit \\
$>$ & Pendidik mengucapkan salam, melakukan presensi, \\
& menyiapakan perangkat .pembelajaran. \\
$>$ & Pendidik melakukan apersepsi (pendidik mengajak \\
& peserta didik berimajinasi dengan memposisikan pada \\
zaman sebelum Indonesia sekarang) & \\
\hline
\end{tabular}




\begin{tabular}{|c|c|c|}
\hline $\begin{array}{l}> \\
>\end{array}$ & $\begin{array}{l}\text { Pemdidik memotivasi (memberi contoh tentang } \\
\text { manfaat mempelajari sejarah) } \\
\text { Pendidik menyampaikan tujuan pembelajaran } \\
\text { Pendidik membentuk kelompok diskusi }\end{array}$ & \\
\hline $\begin{array}{r}\text { Kegiat } \\
> \\
> \\
> \\
> \\
> \\
>\end{array}$ & $\begin{array}{l}\text { an Inti } \\
\text { Pendidik membagi beberapa topik terkait materi } \\
\text { Masing-masing kelompok mengindektifikasi masalah } \\
\text { Masing-masing kelompok membuat hipotesis } \\
\text { Masing-masing kelompok mengumpulkan data dan } \\
\text { menguji kebenaran hipotesisnya melalui bahan ajar } \\
\text { yang sudah disediakan } \\
\text { Masing-masing kelompok menginterpretasi data } \\
\text { Masing-masing kelompok mengembangkan } \\
\text { kesimpulan tentatif atau generalisasi } \\
\text { Masing-masing kelompok menguji jawabannya }\end{array}$ & 110 Menit \\
\hline $\begin{array}{c}\text { Penutc } \\
> \\
> \\
>\end{array}$ & $\begin{array}{l}\text { Masing-masing kelompok menerapkan isi jawabannya } \\
\text { Masing-masing kelompok merevisi kesimpulannya } \\
\text { Pendidik dan peserta didik mengamil kesimpulan dan } \\
\text { mengucapkan salam sebagai tanda akhir pertemuan }\end{array}$ & 15 Menit \\
\hline
\end{tabular}

\section{Penilaian}
$>$ Sikap
: Observasi/Pengamatan
$>$ Pengetahuan : Uji Kompetensi
$>$ Keterampilan : Penilaian tugas kelompok

\section{KESIMPULAN}

Tulisan ini telah menjelaskan tentang posisi matapelajaran sejarah pada tingkat SMK serta memanfaatkan materi lokal yang sesuai dengan lingkungan, kejuruan peserta didik khususnya pada peserta didik di SMK Migas Cepu. Dengan dinamika pembelajaran sejarah di SMK yang mulai berkurang kebermaknaannya, jam pelajarannya serta padatnya materi yang ada, tanpa mengurangi tujuan pembelajaran sejarah di sekolah materi lokal yang terkait dengan kejuruan sangat tepat sekali untuk diajarkan dan dikembangkan. Sehingga dengan mengajarkan sejarah yang sesuai dengan kejuruannya akan sangat terkait dengan konsep di SMK yaitu link and match. Dengan belajar sejarah yang sesuai dengan kejuruannya peserta didik akan mendapatkan bekal ilmu pengetahuan sejarah apabila nanti mereka bekerja atau kuliah di dunia perminyakan.

Keterbatasan penelitian ini terletak pada sifatnya yang masih konseptual, sehingga dibutuhkan penelitian yang lebih mendalam supaya pembelajaran sejarah mendapatkan tempat dan makna yang sesuai khususnya pada tingkat SMK.

\section{DAFTAR PUSTAKA}

Alfian, Magdalia. 2011. "Pendidikan Sejarah Dan Permasalahan Yang Dihadapi." Khazanah Pendidikan 3 (2).

Creswell, John W. 2015. "Penelitian Kualitatif \& Desain Riset: Memilih Diantara Lima Pendekatan." Yogyakarta: Pustaka Pelajar.

Fachrurozi, Miftahul Habibi. 2016. "Prosiding Seminar Nasional Program Studi Pendidikan Sejarah Se-Indonesia: Kajian Muatan Dan Posisi Mata Pelajaran Sejarah Di Kurikulum 2013." In Pembelajaran Sejarah Di SMK Dalam Konteks Globalisasi, edited by Dr. Agus Mulyana (UPI Bandung), M. Pd. (UNY) Dr. Dyah Kumalasari, and Dr. Aman (UNY). Yogyakart: Tim Penerbit Fakultas IImu Sosial 
Universitas Negeri Yogyakarta.

Hasan, S H. 2006. "Pembelajaran Sejarah Yang Mencerdaskan: Mungkinkah." Pendidikan Sejarah, Universitas Pendidikan Indonesia.

Minister of Education and Culture. 2018. "Struktur Kurikulum Sekolah Menengah Kejuruan (SMK)/Madrasah Aliyah Kejuruan (MAK)." Presidential Instruction, no. 021: 307. http://psmk.kemdikbud.go.id/konten/3824/struktur-kurikulum-smkperdirjen-dikdasmen-no-07dd5kk2018-tanggal-7-juni-2018.

Moleong, Lexy J. 2007. "Metodologi Penelitian Kualitatif, Bandung." Penerbit PT Remaja Rosdakarya Offset.

Novina Suprobo. 2018. "Teori Humanistik."

Nur Fajar, Absor, Umasih Umasih, and Kurniawati Kurniawati. 2019. "Pembelajaran Sejarah Di SMK Era Revolusi Industri 4.0: Tantangan Dan Peluang." Jurnal Teori Dan Praksis Pembelajaran IPS 4 (2): 59-65. https://doi.org/10.17977/um022v4i22019p059.

Pratama, Rinaldo Adi, and Nur Indah Lestari. 2019. "Dinamika Pelajaran Sejarah Indonesia Dalam Kurikulum 2013 Pada Jenjang SMK/MAK." Jurnal Pendidikan Sejarah 8 (2): 99-121.

Sartono, Kartodirdjo. 1992. Pendekatan IImu Sosial Dalam Metodologi Sejarah. Gramedia Pustaka Utama.

Suharno, Nugroho Agung Pambudi, and Budi Harjanto. 2020. "Vocational Education in Indonesia: History, Development, Opportunities, and Challenges." Children and $\begin{array}{lllll}\text { Youth Services } & \text { Review } 115 & \text { (May): } & 105092 .\end{array}$ https://doi.org/10.1016/j.childyouth.2020.105092.

Wijayanti, Yeni. 2017. "Peranan Penting Sejarah Lokal Dalam Kurikulum Di Sekolah Menengah Atas." Jurnal Artefak 4 (1): 53-60.

Yuliana, Anisa. n.d. "Pembelajaran Sejarah Lokal, Nilai-Nilai Dan Aplikasi." In Prosiding Seminar Nasional Program Studi Pendidikan Sejarah Se-Indonesia: Kajian Muatan Dan Posisi Mata Pelajaran Sejarah Di Kurikulum 2013, 32. 